\title{
The effect of music on parameters of fear, pain and anxiety during dental care: an integrative review
}

Dalila de Borba Agliatia ${ }^{a}$, Paulo Oliva de Borba ${ }^{a}$, Raul Antônio Cruz ${ }^{a}$, Myrian Camara Brew ${ }^{a}$, Flávio Renato Reis de Moura ${ }^{a}$, Caren Serra Bavaresco ${ }^{a}$

\begin{abstract}
OBJECTIVE: Integrative review on the influence of music on parameters of fear, pain and anxiety during dental care.

METHODS: Search for articles on the databases MEDLINE, PubMed, LILACS, Scielo and Google Scholar, using the terms "music", "dentistry", "music therapy", "fear", "pain", "anxiety" and "music therapy and dentistry". Inclusion criteria were: randomized clinical trials with primary data surveys that were related only to dentistry. The exclusion criteria were: any other experimental and observational study design, literature reviews and studies in which it was not possible to identify a relation with the subject.

RESULTS: Of the 11 randomized trial studies reviewed, all observed beneficial effects in patients who were listening to music during dental care. Studies have shown a reduction of pain during orthodontic treatment, reduction of postoperative recovery time and reduction of anxiety level in pediatric patients. CONCLUSION: It was possible to observe that the use of music is recommended as an accessory therapy in dental care. Nevertheless, for the professional's success in the treatment of fear, pain and anxiety, dialogue with the patient is essential, giving simple explanations and demonstrations, thus reducing the anxiety caused by the unknown and, in this way, controlling fear and pain. However, it is necessary to carry out more research in this field, in order to obtain better scientific evidence regarding music therapy applied to dental practice.
\end{abstract}

Keywords: music therapy; anxiety; fear; pain; dentistry.

\section{Efeito da música nos parâmetros de medo, dor e ansiedade durante o atendimento odontológico: uma revisão integrativa}

\section{RESUMO}

OBJETIVO: Revisão integrativa sobre a influência da música em parâmetros de medo, dor e ansiedade durante atendimento odontológico.

MÉTODOS: busca de artigos na base de dados MEDLINE, PubMed, LILACS, Scielo e Google Acadêmico, tendo como descritores os termos "music", "dentistry", "music therapy", "fear", "pain", "anxiety" e "musicoterapia e odontologia". Os critérios de inclusão foram: ensaios clínicos randomizados que utilizaram dados primários relacionados com o tema proposto neste trabalho. Os critérios de exclusão foram: qualquer outro desenho de estudo experiemntal e observacional, revisões de literatura e quando não foi possível estabelecer relação com o tema do estudo.

RESULTADOS: Dos 11 artigos revisados, todos observaram efeitos benéficos em pacientes que foram atendidos ouvindo música. Os estudos comprovaram redução da dor durante o tratamento ortodôntico, redução do tempo de recuperação pós-operatória e diminuição do nível de ansiedade em pacientes pediátricos.

CONCLUSÃO: Observou-se que o uso da música é recomendado como terapia coadjuvante do atendimento odontológico. Ainda que, para o sucesso pelo profissional no tratamento do medo, dor e ansiedade, é fundamental o diálogo com o paciente, dando explicações e demonstrações simples, podendo diminuir assim a ansiedade causada pelo desconhecido e, deste modo, controlar o medo e a dor. Todavia, é necessária a realização de mais pesquisas nesse campo, para se obter melhores evidências científicas em relação à musicoterapia aplicada à prática odontológica.

Palavras-chave: musicoterapia; ansiedade; medo; dor; odontologia. a School of Dentistry, Lutheran University of Brazil (ULBRA), Canoas, Brazil

Access 


\section{INTRODUCTION}

Music is present in most moments. In everyday life, there are several types of sounds that stimulate different effects and reactions in the body. It is believed that the perception of sound involves the primary, secondary and tertiary areas of the auditory system, as well as areas of the temporal lobes and the Wernicke area, the latter being linked to the perception of language and processing of most of the brain's intellectual functions.

The primary areas receive signals from the inner ear through the thalamus and are involved in the early stages of musical perception, such as pitch frequency, melodic contours, and volume. Secondary areas process more complex patterns of harmony, melody, and rhythm. The tertiary areas allow a general perception of music [1].

In addition to activating other areas of the brain, its processing affects the mesolimbic dopaminergic pathways, which justifies the anxiolytic effect by generating positive reinforcement and reward responses [2]. Moreover, music can influence the emotional state of the individual through the production of physiological reactions whose magnitude seems to depend on the individualized emotional content, being able to influence the whole body through the emotional and physiological reactions [3].

Music has great influence on people's lives. It makes them travel, recall moments and feelings of the past, leaving them happy or sad, influencing them quickly, consciously or unconsciously. It is possible to observe that when people listen to music, a series of images are produced, regardless of their musical preference; that is, music contains a potential for evoking them, which is not a unit of measure per se, but enables quantitative comparison. The reason for that is that the brain transforms almost all experiences into mental images. Music, through its expression of rhythm, melody, form, tone, harmony, timbre, instrumentation, and voices, encompasses all levels of the human being, and the tone of the musical structure affects the flow of images, leading the individual to the idea that different songs, with different musical structures, may also present different potentials to evoke the imagination [4]. In relation to the cognitive sphere, several authors described that through music therapy, it was possible to improve verbal cooperation and communication, as well as to reduce mental confusion in the elderly with dementia during the bath [5-7]. These and other authors have proved that the benefit of music in the psycho-emotional sphere, in relation to the reduction of anxiety and psychomotor agitation, improves aggressive behavior, promoting the sensations of well-being, of joy and of happiness [5-10].

There are mechanisms by which music works to reduce anxiety. The first is the Gate Control Theory of Pain, proposed by Ronald Melzack and Patrick Wall [11]. This theory states that pain signals are transmitted from the injury site, through receptors in the spinal cord, to synapses that receive pain information in the brain. It is believed that music sends enough concurrent sensory inputs through descending pathways of the brain to cause the brain stem to signal some of the closed gates, thereby reducing the amount of pain the patient hearing the music perceive [11].

Another mechanism is distraction. Noguchi [12] describes distraction as "any technique that diverts attention from a noxious stimulus, such as the sound of the dentist's hand instrument scraping a rough tooth surface". The final mechanism is disguise: music is capable of "camouflaging" unpleasant sounds, such as the noises of the dental drill or the sound of the sucker, thus avoiding the patient's anxiety [13].

A clinical trial evaluated 84 children and adolescents, aged 1 to 16 years old, in the first 24 postoperative hours of cardiac surgery. They underwent a thirty-minute session of music therapy, listening to classical music, and were observed, both at the beginning and at the end of the appointment, in regards to heart and respiratory rate, blood pressure, temperature, and other variables, as well as the facial pain scale. Statistically significant differences between the two groups were observed after the intervention for objective assessments of heart and respiratory rates $(p=0.04$ and $p=0.02)$ and subjective evaluation of the pain scale $(p<0.001)$, concluding that there was a beneficial action of music [14].

Kristjansdottir and Kristjansdottir [15] played different music recitals during polio vaccination for 128 adolescents, in a randomized controlled trial. The authors divided the participants into three groups: the first group listened to music with headphones; the second group listened to background music without headphones; and the third group did not undergo any distractions. It was observed that the pain scores of the groups that listened music were significantly lower than the control group, with the lowest pain score being in the group listening to music with headphones.

Therefore, music is a great therapeutic tool, of simple utilization and access, and without side effects, which can be used in various contexts and for various diseases [16-17]. With regard to dentistry, many of the patients, when arriving for dental care, present some phobia for dental practice, the most common being fear, pain and anxiety. The noises of various instruments operating in the mouth, the long period of time that the patient is left with the mouth open, bleeding and/or fear of needles, constitute as potential anxiogenic agents, influencing the patients' responses.

According to Kim et al. [18], patients undergoing the extraction of mandibular impacted third molars may present severe perioperative anxiety, which may lead to increased perceptions of pain, as well as to the instability vital signs during the surgery. In the study conducted by the authors, it was possible to verify that the use of music, chosen by the patient, during the exodontic procedure significantly decreased the levels of intraoperative anxiety of the patient.

Thus, the present study aimed to present an integrative review on the effect of music on parameters of fear, pain and anxiety during dental care. 


\section{METHODS}

For the development of this study, an integrative review was carried out to understand what was present in the national and international scientific literature on the theme "effect of music on fear, pain and anxiety parameters during dental care". Without filters to determine the time period, searches were done in the MEDLINE, PubMed, LILACS, Scielo and Google Academic databases during the months of February, March, August and September of 2017.

For the search strategy, the terms used in the Health Sciences Descriptors (DeCS) were in English, being "music", "dentistry", "music therapy", "fear", "pain" and "anxiety". Also, with the purpose of a greater projection of the results of this investigation, a research was done with Google Scholar with the terms in the Portuguese language ("musicoterapia" e "odontologia") to cover the gray literature, including indexed articles, theses, dissertations and course completion work.

The titles and abstracts of all articles found were independently read by a researcher. Inclusion criteria were: randomized clinical trials with primary data surveys that were related only to dentistry. The exclusion criteria were: any other experimental or observation study design, literature reviews and studies in which it was not possible to identify a relation with the subject.

At the end of the categorization and analysis of the studies, an interpretation of the findings was performed, and its synthesis is presented in tables with informations of the selected studies.

\section{RESULTS}

From the search in the established databases, 708 studies were obtained. After reading all the titles and abstracts, respecting the inclusion and exclusion criteria, 691 studies were excluded, leaving a total of 17 studies to be read in their entireties. For a descriptive analysis, only 11 studies were included. Figure 1 summarizes, through a flowchart, the search performed in the queried databases.

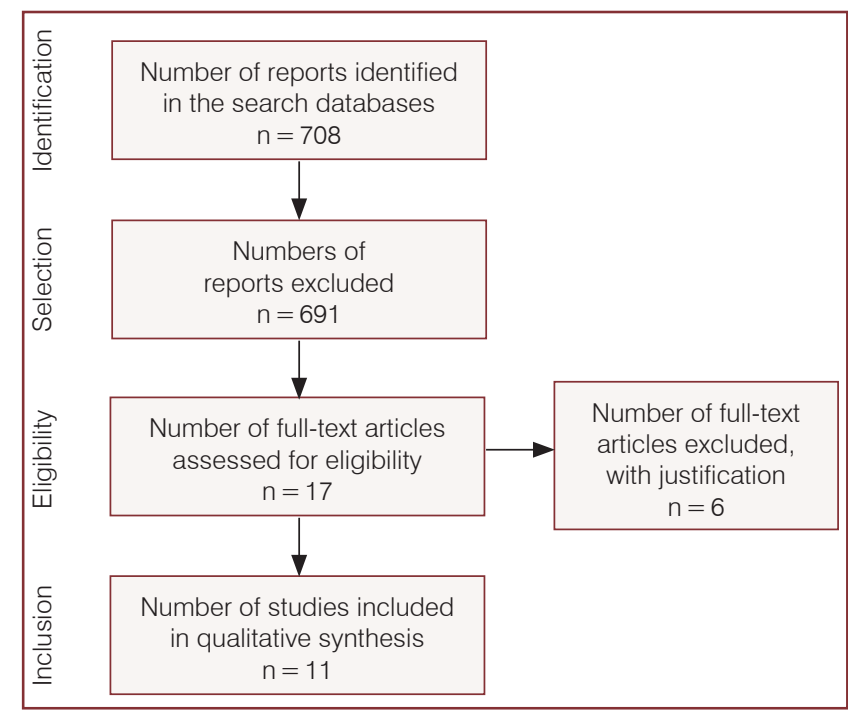

Figure 1. The Flowchart of preferred items for systematic analysis and meta-analyzes (PRISMA).

Five studies [19,20,23,26,28] were conducted in pediatric patients (children and adolescents). Regardless of the methodology used and the results found to have or not being statistically significant, all studies observed that music was a pleasant feature and could decrease anxiety levels.

Similar results were also observed in the different studies where the sample consisted of adults $[21,22,23,24,25,27]$.

The 11 studies included in this integrative review can be observed in summary form, adding information about the authors/year/country, purpose/methods and results (Table 1).

Table 1. List of studies included in qualitative synthesis, according to authors/year/country, purpose/methods and results.

\begin{tabular}{|c|c|c|}
\hline Authors/Year/Country & Purpose and Methods & Results \\
\hline $\begin{array}{l}\text { Aitken et al., } 2002 \text { (Ohio, } \\
\text { USA) [19] }\end{array}$ & $\begin{array}{l}\text { PURPOSE: to determine if audio distraction could decrease } \\
\text { patient anxiety, pain and disruptive behavior during pediatric } \\
\text { dental procedures. } \\
\text { METHODS: } \\
\text { - } 45 \text { children between the ages of } 4 \text { to } 6 \text { years } \\
\text { - two visits for dental care } \\
\text { - restorative dentistry and local anesthesia in a mandibular } \\
\text { quadrant } \\
\text { - visit \#1: baseline session for all patients } \\
\text { - visit \#2: the children were assigned to either an upbeat } \\
\text { music group (group 1), a relaxing music group (group 2) } \\
\text { or a no music group (control group) } \\
\text { - variables measured were: (1) parent-reported anxiety } \\
\text { via the Modified Corah's Anxiety Scale, (2) self-reported } \\
\text { anxiety via the Venham picture scale, (3) heart rate, } \\
\text { (4) behavior via the North Carolina Behavior Rating Scale } \\
\text { and (5) pain via a visual analogue scale. }\end{array}$ & $\begin{array}{l}\text { - no significant difference in self-reported dental anxiety, } \\
\text { cardiac frequency, or preoperative and postoperative } \\
\text { scores among the } 3 \text { groups at visit \#1 or visit \#2 } \\
\text { - strong correlation between the preoperative } \\
\text { measurements at visit \#1 and visit \#2 ( } r=0.60 \text {, } \\
p<0.001 \text { ) } \\
\text { - strong correlation between the postoperative } \\
\text { measurements of visit \#1 and visit \#2 ( } r=0.56, \\
p<0.001 \text { ) } \\
\text { - no significant difference in pain reported between groups } \\
\text { at any of the visits (variance analysis) } \\
\text { - no significant differences were found between the three } \\
\text { groups during the second visit in all variables } \\
\text { - most patients }(90 \%) \text { said they liked the song and would } \\
\text { like to hear it during their next visit. }\end{array}$ \\
\hline
\end{tabular}


Table 1 (continued)

\begin{tabular}{|c|c|c|}
\hline Authors/Year/Country & Purpose and Methods & Results \\
\hline $\begin{array}{l}\text { Marwah et al., } 2005 \\
\text { (India) [20] }\end{array}$ & $\begin{array}{l}\text { PURPOSE: to ascertain if music distraction is an effective } \\
\text { means of managing anxiety in pediatric dental patients. } \\
\text { METHODS: } \\
\text { - } 40 \text { children, between } 4 \text { and } 8 \text { years } \\
-2 \text { groups: control group (group A) and music group } \\
\text { (group B) } \\
\text { - for anxiety - Venham's picture test, Venham's anxiety } \\
\text { rating scale, pulse rate, and oxygen saturation during } \\
\text { different treatment visits. }\end{array}$ & $\begin{array}{l}\text { - audio distraction did decrease the anxiety level in } \\
\text { pediatric dental patients, but not to a very significant } \\
\text { level. }\end{array}$ \\
\hline $\begin{array}{l}\text { Lai et al., } 2008 \\
\text { (Taiwan) [21] }\end{array}$ & $\begin{array}{l}\text { PURPOSE: to evaluate the effects of music on the state } \\
\text { of anxiety and physiological indices among patients } \\
\text { undergoing root canal treatment. } \\
\text { METHODS: } \\
\text { - randomized investigador-blind controlled trial } \\
\text { - } 44 \text { patients, } 18 \text { to } 65 \text { years } \\
-2 \text { groups: (1) music group listened to selected } \\
\text { sedative music using headphones through procedures; } \\
\text { and (2) the control group worn headphones without } \\
\text { music } \\
\text { - repeated measures design; single pretest; five } \\
\text { posttests } \\
\text { - to measure - heart rate, blood pressure and finger } \\
\text { temperature - measured before the study and every } \\
10 \text { minutes until the end of the procedure } \\
\text { - anxiety was measured before the study and at the end } \\
\text { of the treatment procedure. }\end{array}$ & $\begin{array}{l}\text { - no significant differences between the two groups for } \\
\text { baseline data and procedure-related characteristics, } \\
\text { except for gender } \\
\text { - significant increase in finger temperature and a decrease } \\
\text { in anxiety score over time were observed in the music } \\
\text { group when compared with the control group. }\end{array}$ \\
\hline $\begin{array}{l}\text { Ringman et al., } 2009 \\
\text { (Sweden) [22] }\end{array}$ & $\begin{array}{l}\text { PURPOSE: to compare preoperative midazolam with } \\
\text { relaxing music. } \\
\text { METHODS: } \\
\text { - } 372 \text { patients over } 18 \text { years } \\
\text { - } 2 \text { groups: (1) midazolam group - } 0.05-0.1 \mathrm{mg} / \mathrm{kg} \text { orally e } \\
\text { (2) music group - heard relaxing music } \\
\text { - scale used - State Trait Anxiety Inventory (STAI X-1); } \\
\text { completed by the patients just before and after the } \\
\text { intervention. }\end{array}$ & $\begin{array}{l}\text { - } 177 \text { patients completed the music protocol: STAl-state } \\
\text { anxiety scores were: } \\
\text { - before intervention: } 34 \text { (mean - M) and } 8 \text { (standard } \\
\text { deviation - SD) } \\
\text { - after intervention: } 30 \mathrm{M} \text { and } 7 \mathrm{SD} \\
\text { - } 150 \text { patients in the midazolam group: STAl-state anxiety } \\
\text { scores were: } \\
\text { - before intervention: } 36 \mathrm{M} \text { and } 8 \mathrm{SD} \\
\text { - after intervention: } 34 \mathrm{M} \text { and } 7 \mathrm{SD} \\
\text { - a significantly greater decline of the STAI-state anxiety } \\
\text { score was in the music group when compared with the } \\
\text { midazolam group. }\end{array}$ \\
\hline $\begin{array}{l}\text { Kim et al., } 2011 \\
\text { (Korea) }[18]\end{array}$ & $\begin{array}{l}\text { PURPOSE: To evaluate the anxiolytic effects of music } \\
\text { intervention during exodontia and the possible positive } \\
\text { effects on patients' vital signs, anxiety levels and } \\
\text { perceptions of pain. } \\
\text { METHODS: } \\
\text { - } 219 \text { patients, male, age } 40 \text { years } \\
\text { - undergoing 3rd impacted lower molar surgery } \\
\text { - } 2 \text { groups: (1) music treat group ( } n=106 \text {; patient favorite } \\
\text { song was selected) and (2) control group ( } n=113 \text { ) } \\
\text { - Dental Anxiety Scale - used to measure perioperative } \\
\text { anxiety } \\
\text { - Visual Analog Scale - used to measure perceptions } \\
\text { of pain } \\
\text { - patients' vital signs (blood pressure, heart rate, and } \\
\text { respiratory rate) were monitored throughout the } \\
\text { surgery. }\end{array}$ & $\begin{array}{l}\text { - for both groups: } \\
\text { - vital signs increased from baseline to initial incision } \\
\text { (higher values) } \\
\text { - decreased quickly after initial incision and plateaued } \\
\text { within normal limits } \\
\text { - for blood pressure: no significant differences between } \\
\text { groups were found } \\
\text { - for music-treated group when compared to control group, } \\
\text { it was observed: } \\
\text { - a significantly smaller change in heart rate } \\
\text { - a significantly less intraoperative anxiety. }\end{array}$ \\
\hline $\begin{array}{l}\text { Durán et al., 2012 } \\
\text { (Colombia) [23] }\end{array}$ & $\begin{array}{l}\text { PURPOSE: Music therapy efficacy for anxiety control } \\
\text { during the dental prevention treatment in patients with } \\
\text { Down syndrome. } \\
\text { METHODS: } \\
\text { - voluntary participation of } 30 \text { children between } 5 \text { and } 14 \\
\text { years old with Down syndrome } \\
\text { - } 2 \text { experimental groups: (1) control group and (2) group } \\
\text { exposed to music } \\
\text { - Corah's scale - to measure parents' degree of anxiety } \\
\text { - Faces analog scale - to measure children's anxiety, } \\
\text { before, during and after the procedure } \\
\text { - Frankl's scale - to measure children's behavior during } \\
\text { the consult } \\
\text { - change in heart rate and blood pressure was also } \\
\text { measured. }\end{array}$ & $\begin{array}{l}\text { - for the level of anxiety and behavior, } 80 \% \text { of the children } \\
\text { in the music group showed no anxiety and } 27 \% \text { in the } \\
\text { control group } \\
\text { - heart rate showed a reduction in the group exposed to } \\
\text { music therapy }(p>0.05) \\
\text { - music therapy significantly reduced anxiety levels in the } \\
\text { group exposed to music. }\end{array}$ \\
\hline
\end{tabular}


Table 1 (conclusion)

\begin{tabular}{|c|c|c|}
\hline Authors/Year/Country & Purpose and Methods & Results \\
\hline $\begin{array}{l}\text { Xiaomei et al., } 2013 \\
\text { (China) [24] }\end{array}$ & $\begin{array}{l}\text { PURPOSE: to discuss the effect of music on pain relief } \\
\text { during orthodontic treatment (linear wire apparatus for } \\
\text { bimaxillary treatment) for the first time } \\
\text { METHODS: } \\
\text { - } 175 \text { patients, age } 11 \text { to } 35 \text { years } \\
-2 \text { groups: (1) with music and (2) without music }\end{array}$ & $\begin{array}{l}\text { - group music: } \\
\text { - it was observed significantly less pain than the group } \\
\text { - without music }(p<0.05) \\
\text { - pain was stronger in women than in men }(p<0.05) \\
\text { - for both groups, pain was stronger in patients with an } \\
\text { introversion/irritability tendency when compared to those } \\
\text { with extrovert/calm }(p<0.05) \\
\text { - music helped ease the pain during orthodontic treatment. }\end{array}$ \\
\hline $\begin{array}{l}\text { Thoma et al., } 2015 \\
\text { (Swiss) [25] }\end{array}$ & $\begin{array}{l}\text { PURPOSE: to examine the effect of music on pre-treatment } \\
\text { anxiety in a healthy patient sample waiting for scheduled } \\
\text { dental hygiene treatment. } \\
\text { METHODS: } \\
\text { - } 92 \text { consecutive volunteer patients (mean age, } 57 \text { years), } \\
\text { randomly allocated } \\
-2 \text { groups: (1) Experimental group ( } n=46 \text { ), listening to } \\
\text { music for } 10 \text { min; (2) Control Group }(n=46) \text {, waiting in } \\
\text { silence } \\
\text { - state and habitual anxiety, subjective stress, and mood } \\
\text { measures were assessed before and after music listening } \\
\text { or silence, respectively. }\end{array}$ & $\begin{array}{l}\text { - experimental group - anxiety levels decreased } \\
\text { significantly after the intervention as compared with the } \\
\text { control group }(F(1 / 90)=8.06, p=0.006) \\
\text { - participants' trait anxiety and dental anxiety were not } \\
\text { found to moderate this effect } \\
\text { - pre-treatment music decreases anxiety levels to a greater } \\
\text { extent than waiting in silently. }\end{array}$ \\
\hline $\begin{array}{l}\text { Navit et al., } 2015 \\
\text { (China) [26] }\end{array}$ & $\begin{array}{l}\text { PURPOSE: To evaluate the efficacy of audio-distraction } \\
\text { aids in reducing the anxiety of pediatric patients when } \\
\text { undergoing various stressful and invasive dental } \\
\text { procedures. } \\
\text { METHODS: } \\
\text { - } 150 \text { children, aged } 6 \text { to } 12 \text { years } \\
\text { - } 5 \text { groups ( }=30 \text {, each group): (1) control group, } \\
\text { (2) instrumental music group, (3) musical nursery rhymes } \\
\text { group, (4) the movie songs group and (5) group of audio } \\
\text { stories } \\
\text { - four visits to each child } \\
\text { - test were performed after the procedures was completed } \\
\text { - Venham's Picture Test (VPT) and Venham's Clinical Rating } \\
\text { Scale (VCRS) were used to measure anxiety levels } \\
\text { - pulse rate measurement was performed.with the help } \\
\text { of pulse oximeter. }\end{array}$ & $\begin{array}{l}\text { - between all the groups: } \\
\text { - for the mean pulse rate, a significant difference was } \\
\text { observed, with an increase in subsequent visit } \\
\text { - no significant difference was observed in the VPT and } \\
\text { VCRS scores } \\
\text { - audio aids in general reduced anxiety in comparison to } \\
\text { the control group } \\
\text { - the most significant reduction in anxiety level was } \\
\text { observed in the audio stories group }\end{array}$ \\
\hline $\begin{array}{l}\text { Mejía-Rubalcava et al., } \\
2015 \text { (Mexico) [27] }\end{array}$ & $\begin{array}{l}\text { PURPOSE: to evaluate the effect of music on anxious } \\
\text { patients in relation to dental care. } \\
\text { METHODS: } \\
\text { - } 34 \text { patients (18 years and older) randomly assigned } \\
\text { - } 2 \text { groups: (1) control; (2) experimental } \\
\text { - salivary cortisol, stimulate salivary flow, blood pressure, } \\
\text { heart rate, oxygen saturation and body temperature were } \\
\text { measure } \\
\text { - Student t-test and Chi2 were applied to analyze significant } \\
\text { differences between the studied variables before and } \\
\text { after the unpleasant stimulation causes anxiety for dental } \\
\text { treatment. }\end{array}$ & $\begin{array}{l}\text { - in the first measure: both groups registered the same } \\
\text { level of anxiety } \\
\text { - in the second measurement, significant differences were } \\
\text { registered in the salivary cortisol concentration, systolic } \\
\text { and diastolic pressure, heart rate, body temperature } \\
\text { and stimulated salivary flow for treated group with music } \\
\text { therapy } \\
\text { - the scores of the modified dental anxiety scale were } \\
23.1 \pm 0.9 \text { and } 22.4 \pm 1.1 \text { for the control group and for the } \\
\text { experimental group, respectively } \\
\text { - there were no significant differences between groups } \\
\text { - music therapy has a positive effect in control of dental } \\
\text { anxiety. }\end{array}$ \\
\hline $\begin{array}{l}\text { Ozkalayci et al., } 2016 \\
\text { (Turkey) [28] }\end{array}$ & $\begin{array}{l}\text { PURPOSE: to investigate the effects of listening to music } \\
\text { or providing sound isolation on the depth of sedation and } \\
\text { need for sedatives in pediatric dental patients submitted to } \\
\text { tooth extraction, filling, root treatment and amputation. } \\
\text { METHODS: } \\
\text { - prospective, randomized, and controlled study } \\
\text { - } 180 \text { patients (between } 13 \text { and } 15 \text { years) } \\
\text { - } 3 \text { groups: (1) music group (Vivaldi - Four Seasons with } \\
\text { headphone), (2) isolation with headphone, but no music } \\
\text { and (3) control } \\
\text { - all patients were sedated by } 0.1 \mathrm{mg} / \mathrm{kg} \text { midazolam and } \\
1 \text { mg/kg propofol } \\
\text { - during the procedure, an additional } 0.5 \mathrm{mg} / \mathrm{kg} \text { propofol } \\
\text { was administered as required. }\end{array}$ & $\begin{array}{l}\text { - the sedation level, amount of medication, and } \\
\text { hemodynamic were not significantly altered to music or } \\
\text { providing sound isolation during the procedures } \\
\text { - the authors suggested that this result might be due to the } \\
\text { deep sedation levels reached during the procedures } \\
\text { - postoperative recovery duration might have be shortened } \\
\text { by the listening to music and providing sound isolation. }\end{array}$ \\
\hline
\end{tabular}




\section{DISCUSSION}

A large number of people enjoy listening to music at various times, such as when dancing, remembering ancestors and distant people, to meditate or pray, as well as to relax and to get emotional. The use of music, in this review, was positive, bringing benefits to patients during dental care.

The International Association for the Study of Pain (IASP) has described pain as an unpleasant sensory, emotional, and behavioral state that originates in any region of the body, and that depends on tissue damage or may be affected by past experiences of the individual [29].

Anxiety is a physiological characteristic of human beings, a characteristic that precedes a real or imagined danger. Generally, its symptoms are: tachycardia, sweating, tightness in the chest, feeling of emptiness in the stomach, and intense fear. Some people, both adults or children, feel this sensation when they have a dentist's appointment, either as a result of some kind of already experienced trauma, or because of a sensation of imaginary danger or fear of the unknown [30].

Many patients arrive at the dental clinic with traumas resulting from more aggressive dental interventions, and it is necessary to develop strategies to minimize this negative feeling. It was observed in the studies of this integrative review that listening to music during dental procedures reduces pain, anxiety and aggressive behaviors [11].

Concerning pain, Xiaomei et al. [24] demonstrated that the group of patients exposed to music showed significantly less pain than the control group, and the painful sensation was stronger in patients with a tendency to introversion in comparison to those prone to extraversion. Similar results in relation to pain reduction were observed in patients who listened to music during orthodontic treatment, according to Koritsánszky, Madléna [31]. The authors noted that 95\% of patients reported experiencing pain during orthodontic treatment. The pain started within 4 hours, increased over the next 24 hours and decreased within 7 days; therefore, pain cannot be identified by the orthodontist on a return visit. This performance may be related to the synthesis and secretion of nerve factor. In this study, pain alterations in the music group also follow this rule, the peak pain after 24 hours of treatment being consistent with the control group.

In the same context, evidence suggests that music has a greater positive impact on patients undergoing surgical procedures under regional anesthesia, through the reduction of anxiety and fear related to sounds from the operating room. For Ozkalayci et al. [28], there was a reduction in the postoperative recovery time in pediatric patients submitted to dental extraction, filling, treatment or root amputation.

On the other hand, patients awaiting surgery often suffer from fear and anxiety, which can be prevented through the use of anxiolytic drugs. However, the use of music therapy may be an alternative treatment with fewer adverse effects. In the study by Ringman et al. [22], relaxing music decreases the level of anxiety in a preoperative environment to a greater extent than a commonly used dose of orally administered midazolam, and has no side effects. The music also seems to affect the perception of acute pain during painful procedures, reducing both analgesic requirements and pain scores, depending on the severity of the stimuli.

For Yeung et al. [32], the cheapest and least timeconsuming methods in practice for reducing dental anxiety are the use of lavender scent and musical distraction. To maximize the effect, patients should select the music with which they are familiar. However, no method provides any long-term effects on anxiety reduction. According to Thoma et al. [25], listening to music before dental hygiene treatment decreases anxiety levels to a greater extent than waiting in silence.

It is of great importance to have a relationship of trust between the dental surgeon and the patient, since both tend to be anxious if the treatment is difficult. The anxious patient can make sudden movements, which are capable of causing a wrong maneuver and, consequently, an injury. The patient should always report his or her fears and expectations in an honest conversation with the professional, thus establishing a bond of trust [30-33]. Thus, it is possible to enjoy alternative resources to soften these unpleasant sensations, making the procedure more comfortable for both the professional and the patient.

The art of music therapy brings out the possibility of innovation in health care, providing quality of life during the treatment period. Therefore, music therapy can be an effective alternative, regardless of the professional who employs it [34].

\section{CONCLUSION}

Studies show that music therapy allows for sensations of joy, happiness, well-being, relaxation, routine change, entertainment, reduction of painful symptoms, positive memories, companionship, and a sensation of faster passing of time. The use of music is recommended as an accessory therapy of dental care, as it is inexpensive, easy to apply, with no side effects, and with a positive impact on the management of patients' pain, fear and anxiety.

The use of music in dental clinics is an important tool to control anxiety, not by identifying an exclusive type of music to be used, but by the possibility of having it as an acoustic background. However, there is still a need for further research in this field in order to obtain more evidence regarding music therapy applied to dental practice.

\section{REFERENCES}

1. Guida HL, Feniman MR, Zanchetta S, Ferrari C, Giacheti CM, Zorzetto NL. Revisão Anatômica e fisiológica do processamento auditivo. Acta ORL 2007;25:177-254

2. Nociti JR. Music and anesthesia [editorial]. Rev Bras Anestesiol 2010 [cited 2016 Mar 25];60(5):455-6. Available at: http://www.scielo.br/pdf/ rba/v60n5/en_v60n5a01.pdf

3. Carter R. The Human Brain Book: an illustrated guide to its structure function and disorders. New York: DK; 2009

4. Buch CA. A música e a terapia das imagens: caminhos para o eu interior. São Paulo: Cultrix; 1995 
5. Clark ME, Lipe AW, Bilbrey M. Use of music to decrease aggressive behaviors in people with dementia. J Gerontol Nurs 1998 July;24(7):10-7. https://doi.org/10.3928/0098-9134-19980701-05

6. Brotons $M$, Koger SM. The impact of music therapy on language functioning in dementia. J Music Ther 2000 Fall;37(3):183-95. https:// doi.org/10.1093/jmt/37.3.183

7. Kydd P. Using music therapy to help a client with Alzheimer's disease adapt to long-term care. Am J Alzheimer's Dis Other Demen 2001 MarApr;16(2):103-8. https://doi.org/10.1177/153331750101600209

8. Todres D. Música é remédio para o coração. Jornal de Pediatria 2006;82(3):166-8. https://doi.org/10.1590/S0021-75572006000300002

9. Juslin PN, Liljeström S, Västfjäl D, Barradas G, Silva A. An experience sampling study of emotional reactions to music: listener, music, and situation. Emotion 2008;8(5):668-83. https://doi.org/10.1037/a0013505

10. Flores-Gutiérrez E, Diaz J. The emotional response to music: attribution of emotion word to musical segments. Salud Mental 2009;32(1):21-34

11. Melzack R, Wall PD. Pain Mechanisms: A New Theory. Survey of Anesthesiology 1967 Apr;11(2):89-90. https://doi.org/10.1097/00132586196704000-00002

12. Noguchi LK. The effects of music versus nonmusic on behavioral signs of distress and self-report of pain in pediatric injection patients. J Music Ther 2006;43(1):16-38. https://doi.org/10.1093/jmt/43.1.16

13. Terpack S, Granbois A. Soothing dental anxiety: music therapy and the dentally anxious patient. Access 2014 Jan;28(1):14-5.

14. Hatem TP, Lira PIC, Mattos SS. Efeito terapêutico da música em crianças em pós-operatório de cirurgia cardíaca. J Pediatr 2006;82(3):186-92. https://doi.org/10.2223/JPED.1473

15. Kristjánsdottir $\mathrm{O}$, Kristjánsdottir $\mathrm{G}$. Randomized clinical trial of musical distraction with and without headphones for adolescents' immunization pain. Scand J Caring Sci 2011 Mar;25(1):19-26

16. Orjuela Rojas JM. Efecto ansiolítico de la musicoterapia: aspectos neurobiológicos y cognoscitivos del procesamiento musical. Rev Colomb. Psiquiatr 2011 [cited 2016 Mar 25];40(4):748-59. Available at: http://www. scielo.org.co/pdf/rcp/v40n4/v40n4a12.pdf

17. Pinto Junior FEL, Ferraz DLM, Cunha EQ, Santos IRM, Batista MC Influência da música na dor e na ansiedade decorrentes de cirurgia em pacientes com câncer de mama. Rev Bras Cancerol 2012 Apr-June [cited 2016 Mar. 25];58(2):135-41. Available at: http://pesquisa.bvsalud.org/ sms/resource/pt/lil-647218

18. Kim YK, Kim SM, Myoung H. Musical intervention reduces patients' anxiety in surgical extraction of an impacted mandibular third molar. American Association of Oral and Maxillofacial Surgeons J Oral Maxillofac Surg 2011 Apr;69(4):1036-45. https://doi.org/10.1016/j.joms.2010.02.045

19. Aitken JC, Wilson S, Coury D, Moursi AM. The effect of music distraction on pain, anxiety and behavior in pediatric dental patients. Pediatr Dent 2002 Mar-Apr;24(2):114-8

20. Marwah N, Prabhakar AR, Raju OS. Music distraction - its efficacy in management of anxious pediatric dental patients. J Indian Soc Pedod Prev Dent 2005 Oct-Dec;23(4):168-70. https://doi.org/10.4103/09704388.19003
21. Lai HL, Hwang MJ, Chen CJ, Chang KF, Peng TC, Chang FM. Randomised controlled trial of music on state anxiety and physiological indices in patients undergoing root canal treatment. J Clin Nurs 2008 Oct:17(19): 2654-60. https://doi.org/10.1111/j.1365-2702.2008.02350.x

22. Bringman $H$, Giesecke K, Thörne A, Bringman S. Relaxing music as pre-medication before surgery: a randomised controlled trial. Acta Anaesthesiol Scand 2009 July;53(6):759-64. https://doi.org/10.1111/ j.1399-6576.2009.01969.x

23. Scarpetta RAG, Arismendy LD, Sosa LJC, Vargas CTP, Becerra NRR Musicoterapia para el control de ansiedade odontológica em ninos com síndrome de down. Hacia la Promoción de la Salud 2012 July-Dec;17(2): 13-24.

24. Xiaomei X, Lihua Z, Yahua J, Yue H, Suhua H, Siwei Y. Clinical musical study on pain relief in orthodontic treatment. West China Journal of Stomatology 2013 Aug;31(4).

25. Thoma MV, Zemp M, Kreienbühl L, Hofer D, Schmidlin PR, Attin T, Ehlert U, Nater UM. Effects of Music Listening on Pre-treatment Anxiety and Stress Levels in a Dental Hygiene Recall Populatiom. Int J Behav Med 2015 Aug;22(4):498-505. https://doi.org/10.1007/s12529-014-9439-x

26. Navit S, Johri N, Khan SA, Singh RK, Chadha D, Navit P, Sharma A, Bahuguna R. Effectiveness and Comparison of Various Audio Distraction Aids in Management of Anxious Dental Paediatric Patients. J Clin Diagn Res 2015 Dec;9(12):ZC05-9. https://doi.org/10.7860/JCDR/2015/15564. 6910

27. Mejía-Rubalcava C, Alanís-Tavira J, Mendieta-Zerón H, Sánchez-Pérez L Changes induced by music therapy to physiologic parameters in patients with dental anxiety. Complement Ther Clin Pract 2015 Nov:21(4):282-6. https://doi.org/10.1016/j.ctcp.2015.10.005

28. Ozkalayci O, Araz C, Cehreli SB, Tirali RE, Kayhan Z. Effects of music on sedation depth and sedative use during pediatric dental procedures. J of Clin Anesth 2016;34:647-53. https://doi.org/10.1016/j.jclinane.2016.07.001

29. Melzack R, Wall PD. Pain mechanisms: a new theory. Science 1965; 50(3699):971-9. https://doi.org/10.1126/science.150.3699.971

30. Pereira VZ, Barreto RC, Pereira GAS, Cavalcanti HRBB. Avaliação dos níveis deansiedade em pacientes submetidos ao tratamento odontológico. Rev. Bras. Cien. Saúde 2013;17(1):55-64

31. Koritsánszky N, Madléna M. Pain and discomfort in orthodontic treatments. Literature review. Fogorv Sz 2011 Dec;104(4):117-21.

32. Yeung Y. Distraction techniques for anxious dental patients an arising field in analgesia for modern dentistry. SAAD Dig 2013 Jan;29:82-7.

33. Possobon RF, Carrascoza KC, Moraes ABA, Costa Junior AL. O tratamento odontológico como gerador de ansiedade. Piscol Estudo 2007 Dec;12(3): 609-16. https://doi.org/10.1590/S1413-73722007000300018

34. Oliveira MF, Oselame GB, Neves EB, Oliveira EM. Musicoterapia como ferramenta terapêutica no setor da saúde: uma revisão sistemática. Revista da Universidade Vale do Rio Verde 2014 Aug-Dec;12(2):871-8. 